\title{
24. GEOCHEMISTRY OF INTERSTITIAL GASES IN SEDIMENTARY DEPOSITS OF THE GULF OF CALIFORNIA, DEEP SEA DRILLING PROJECT LEG $64^{1}$
}

\author{
Eric M. Galimov, V. I. Vernadsky Institute of Geochemistry and Analytical Chemistry, \\ USSR Academy of Sciences, Moscow, USSR \\ and \\ Bernd R. T. Simoneit, ${ }^{2}$ Institute of Geophysics and Planetary Physics, University of California-Los Angeles, \\ Los Angeles, California
}

\begin{abstract}
We analyzed interstitial gases from holes at Sites $474,477,478,479$, and 481 in the Gulf of California, using gas chromatography and stable isotope mass spectrometry to evaluate their composition in terms of biogenic and thermogenic sources. The hydrocarbon gas $\left(\mathrm{C}_{1}-\mathrm{C}_{5}\right)$ concentrations were comparable to the shipboard data, and no olefins could be detected. The $\delta^{13} \mathrm{C}$ data for the $\mathrm{CH}_{4}$ confirmed the effects of thermal stress on the sedimentary organic matter, because the values were typically biogenic near the surface and became more depleted in ${ }^{12} \mathrm{C}$ versus depth in holes at Sites 474,478 , and 481 . The $\mathrm{CH}_{4}$ at Site 477 was the heaviest, and in Hole 479 it did not show a dominant hightemperature component. The $\mathrm{CO}_{2}$ at depth in most holes was mostly thermogenic and derived from carbonates. The low concentrations of $\mathrm{C}_{2}-\mathrm{C}_{5}$ hydrocarbons in the headspace gas of canned sediments precluded a stable carbon-isotope analysis of their genetic origin.
\end{abstract}

\section{INTRODUCTION}

Recent tectonic activity in the Gulf of California has generated extremely diverse thermal conditions within the sedimentary sequences. Some of these sediments show considerable thermal gradients, and already at a depth of several hundred meters sub-bottom, the in situ temperatures correspond to a platform sedimentary sequence that has subsided to a depth of many thousand meters. But the same sedimentary basin has other regions where the heat-flow values do not significantly exceed normal levels. Thus, the geological conditions permit the study of the thermal effects on the transformation of organic matter and the composition of the products resulting from this transformation versus the background of other, more or less constant, conditions (e.g., lithology-facies composition, age of deposits, and the type and source of organic matter).

\section{METHOD}

Interstitial gas samples were collected on board in vacutainers (commercial, evacuated test tubes) and then analyzed on board. Using gas chromatography for $C_{1}-C_{8}$ hydrocarbons under higher gas chromatographic resolution, we reanalyzed the samples. The gas had been stored in the same vacutainers until delivery to the laboratory for analysis.

Quantitative hydrocarbon gas data were obtained using a Hewlett-Packard $5830 \mathrm{~A}$ gas chromatograph connected to a Model $18850 \mathrm{~A}$ control terminal. We used locking gas-tight syringes (Precision Series A $-5.0,1.0$, and $0.25 \mathrm{ml}$ ) for sample injections. The Model $5830 \mathrm{~A}$ is a dual-column gas chromatograph with a flame ionization detector (FID) for the analysis of $\mathrm{C}_{1}-\mathrm{C}_{8}$ hydrocarbons (100-pg detection limit) and a thermal conductivity detector (TCD) for $\mathrm{H}_{2}, \mathrm{CO}, \mathrm{CO}_{2}, \mathrm{CH}_{4}$, $\mathrm{N}_{2}$, and $\mathrm{O}_{2}$ determinations (100-ng detection limit).

The FID was operated only, using the following GC conditions: injection temperature at $180^{\circ} \mathrm{C}$; helium carrier gas $(3.6 \mathrm{ml} / \mathrm{min}$. flow

\footnotetext{
${ }^{1}$ Curray, J. R., Moore, D. G., et al., Init. Repts. DSDP, 64: Washington (U.S. Govt. Printing Office).

2 Present address: School of Oceanography, Oregon State University, Corvallis, Oregon.
}

rate; $20 \mathrm{ml} / \mathrm{min}$. air); column oven programmed $-50^{\circ}(2 \mathrm{~min}$. isothermal) to $+10^{\circ} \mathrm{C}$ at $10^{\circ} \mathrm{C} / \mathrm{min}$., $+10^{\circ}$ to $100^{\circ} \mathrm{C}(45 \mathrm{~min}$. isothermal) at $4^{\circ} \mathrm{C} / \mathrm{min}$.; Durapak stainless steel column ( $n$-octane/Porosil C, $5 \mathrm{~m} \times 0.76 \mathrm{~mm}$ I.D.).

We identified the compounds by comparing their retention times with those of the natural gas components. The individual compounds of natural gas had been identified by gas chromatography-mass spectrometry (Rohrback, 1979). The results of these GC analyses are found in Table 1, and they confirm the shipboard data (see site chapters).

The carbon isotope compositions of $\mathrm{CH}_{4}$ and $\mathrm{CO}_{2}$ were measured in the Laboratory of Carbon Geochemistry of the Institute of Geochemistry and Analytical Chemistry, USSR Academy of Sciences. Barium hydroxide, injected into the vacutainers, bound the carbon dioxide. We then introduced $5 \mathrm{~cm}^{3}$ of the remaining gas, sampled by syringe, into the vacuum system to be incinerated to $\mathrm{CO}_{2}$ in the reactor that consisted of copper oxide heated to $800^{\circ} \mathrm{C}$. The system had appropriate traps for removing $\mathrm{N}_{2} \mathrm{O}, \mathrm{SO}_{2}$, and other impurities. When the precipitated barium carbonate $\left(\mathrm{BaCO}_{3}\right)$ was dry, we then treated it with ortho-phosphoric acid in the standard system; the released $\mathrm{CO}_{2}$ was used to analyze the carbon isotopes. The carbon isotopic composition measurements were performed on a Varian MAT 230 mass spectrometer with an accuracy of $\pm 0.1 \%$ (Galimov et al., 1980). Table 2 is a compilation of the results and gives the " $\delta$ " notation versus the PDB standard.

The headspace of canned sediment samples was analyzed by gas chromatography and the stable carbon and oxygen isotope compositions on $\mathrm{CH}_{4}$ and $\mathrm{CO}_{2}$ determined. The $\delta^{18} \mathrm{O}$ versus standard mean ocean water (SMOW) is also given.

\section{RESULTS AND DISCUSSION}

Table 1 shows the results of the interstitial gas analyses. The concentrations of $\mathrm{CH}_{4}, \mathrm{C}_{2} \mathrm{H}_{6}, \mathrm{C}_{3} \mathrm{H}_{8}$, and total $\mathrm{C}_{4} \mathrm{H}_{10}$ and $\mathrm{C}_{5} \mathrm{H}_{12}$ compare with the shipboard data (see site chapters and Simoneit, this volume). No olefinic hydrocarbons are detectable.

\section{Mouth of the Gulf}

Sites 474 through 476 are at the mouth of the Gulf of California and within the boundary of the continental slope. They lie under water depths of 2500 to $3000 \mathrm{me}$ ters. The sedimentary sequence in Holes 474 and 474A 
Table 1. Hydrocarbon $\left(\mathrm{C}_{1}-\mathrm{C}_{5}\right)$ and carbon dioxide in interstitial gas samples from the Gulf of California (DSDP Leg 64).

\begin{tabular}{|c|c|c|c|c|c|c|c|c|c|c|}
\hline Section & $\begin{array}{l}\text { Sub-bottom } \\
\text { Depth } \\
\text { (m) }\end{array}$ & $\begin{array}{c}\text { Methane } \\
\text { Concentration } \\
(\mathrm{mg} / \mathrm{l})\end{array}$ & $\begin{array}{l}\text { Ethane } \\
(\mu \mathrm{g} / \mathrm{l})\end{array}$ & $\begin{array}{l}\mathrm{C}_{2} / \mathrm{C}_{1} \\
\times 10^{-4}\end{array}$ & $\begin{array}{l}\text { Propane } \\
(\mu \mathrm{g} / \mathrm{l})\end{array}$ & $\begin{array}{c}\mathrm{C}_{4} \mathrm{H}_{10} \\
\text { Total } \\
(\mu \mathrm{g} / \mathrm{l})\end{array}$ & $\begin{array}{c}\mathrm{C}_{5} \mathrm{H}_{12} \\
\text { Total } \\
(\mu \mathrm{g} / \mathrm{l})\end{array}$ & $\begin{array}{c}\text { Neopentane } \\
(\mu \mathrm{g} / \mathrm{l})\end{array}$ & $\begin{array}{c}\text { Carbon } \\
\text { Dioxide } \\
\text { Concentration } \\
(\%)^{\mathrm{a}}\end{array}$ & $\begin{array}{c}\text { Approximate } \\
\text { Thermal } \\
\text { Gradient } \\
\text { Estimate }^{\mathrm{b}}\end{array}$ \\
\hline $474-3-3$ & 14.5 & 375 & 75 & 2.3 & 10 & 2.5 & 8 & 0.1 & 4 & 1 \\
\hline $474 \mathrm{~A}-9-4$ & 245 & 355 & 240 & 8.1 & 49 & 15 & 1.5 & & 4 & 1 \\
\hline $474 \mathrm{~A}-12-4$ & 272 & 83 & 42 & 6.0 & 12 & 5 & 3.5 & & 4 & 2 \\
\hline $474 \mathrm{~A}-24-3$ & 375 & 361 & 299 & 10.0 & 50 & 17 & & & 2 & 3 \\
\hline $474 \mathrm{~A}-26-2$ & 393 & 221 & 149 & 8.1 & 20 & 8 & 7 & & 1 & 5 \\
\hline $474 \mathrm{~A}-28-2$ & 413 & 267 & 175 & 7.8 & 25 & 13 & & & 1 & 5 \\
\hline $474 \mathrm{~A}-40-3$ & 529 & 0.1 & & & 0.5 & & & & & 5 \\
\hline $477-7-1$ & 50 & 0.8 & 5 & 81 & 0.3 & 0.05 & 1.5 & & 0.2 & 1 \\
\hline $477-16-2$ & 117 & 5.2 & 39 & 90 & 30 & 21 & 2 & & 8 & 3 \\
\hline $477-19-3$ & 147 & 118 & 1865 & 190 & 161 & 16 & 0.5 & 0.1 & 32 & 5 \\
\hline $477-20-2$ & 155 & 74 & 462 & 75 & 14 & & 0.5 & & 16 & 8 \\
\hline $477-23-1$ & 182 & 62 & 159 & 31 & 3.5 & & 0.9 & & 1.2 & 10 \\
\hline $478-11-3$ & 92 & 55 & 5 & 1.0 & 4 & 0.3 & & & 2 & 1 \\
\hline $478-14-3$ & 121 & 455 & 35 & 0.9 & 27 & 7 & 9 & & 12 & 1 \\
\hline $478-17-3$ & 149 & 378 & 34 & 1.1 & 26 & 8 & 9 & & 12 & 2 \\
\hline $478-20-4$ & 170 & 348 & 42 & 1.4 & 32 & 1 & & & 20 & 3 \\
\hline $478-22-1$ & 184 & 204 & 35 & 2.0 & 22 & 3 & & 0.05 & 6 & 4 \\
\hline $478-28-3$ & 244 & 285 & 200 & 8.4 & 22 & 5 & 0.05 & & 2 & 6 \\
\hline $478-31-1$ & 260 & 122 & 62 & 6.1 & 5 & 1 & & & 1 & 6 \\
\hline $478-33-3$ & 282 & 68 & 35 & 6.1 & 5 & 0.9 & 0.6 & & 2 & 6 \\
\hline $478-36-2$ & 309 & 99 & 39 & 4.7 & 6 & 0.6 & 1.0 & & 2 & 6 \\
\hline $479-14-6$ & 125 & 237 & 90 & 4.5 & 10 & 0.4 & 1.5 & & 30 & 1 \\
\hline $479-18-2$ & 161 & 252 & 119 & 5.7 & 19 & 0.3 & 2 & & 38 & 1 \\
\hline $479-20-5$ & 180 & 281 & 110 & 4.7 & 16 & 0.3 & 1.3 & & 32 & 1 \\
\hline $479-22-5$ & 198 & 109 & 121 & 13 & 19 & 0.4 & 1.5 & & 33 & 1 \\
\hline $479-24-5$ & 217 & 260 & 107 & 5 & 12 & 0.2 & 1.5 & & 29 & 2 \\
\hline $479-25-2$ & 225 & 224 & 106 & 5.7 & 9 & 0.3 & 1.5 & & 33 & 2 \\
\hline $479-27-5$ & 246 & 246 & 146 & 7 & 9 & 0.7 & 0.5 & & 27 & 2 \\
\hline $479-29-5$ & 266 & 240 & 185 & 9.3 & 8 & 1.0 & 0.7 & & 25 & 3 \\
\hline $479-31-5$ & 285 & 265 & 323 & 14 & 10 & 1.0 & 1.8 & & 24 & 4 \\
\hline $479-34-5$ & 314 & 213 & 285 & 15 & 9 & 1.0 & 0.3 & & 41 & 5 \\
\hline $479-36-2$ & 329 & 85 & 159 & 22 & 6 & 0.9 & 0.9 & & 44 & 6 \\
\hline $479-40-4$ & 370 & 155 & 610 & 47 & 39 & 16.5 & 3.5 & & 33 & 6 \\
\hline $479-43-2$ & 394 & 173 & 309 & 21 & 19 & 25 & 2.5 & & 15 & 6 \\
\hline $479-47-3$ & 435 & 173 & 482 & 21 & 38 & 47 & 5.5 & & 25 & 6 \\
\hline $480-21-2$ & 101 & 3.6 & 1 & 2.8 & 0.2 & & 0.5 & & 1.5 & 1 \\
\hline $480-25-1$ & 119 & 278 & 125 & 5.4 & 22 & 3 & 3 & 0.2 & 6 & 1 \\
\hline $481 \mathrm{~A}-4-1$ & 70.5 & 233 & 214 & 11 & 6 & 2 & 6 & & 2 & 1 \\
\hline $481 \mathrm{~A}-5-3$ & 83 & 401 & 468 & 14 & 11 & 6 & 6 & & 5 & 1 \\
\hline $481 A-7-6$ & 106 & 389 & 391 & 12 & 44 & 195 & 43 & 0.2 & 6 & 1 \\
\hline $481 \mathrm{~A}-9-5$ & 125 & 109 & 336 & 37 & 6 & 0.1 & 4 & 0.05 & 5 & 2 \\
\hline $481 \mathrm{~A}-10-5$ & 135 & 372 & 1097 & 35 & 139 & 177 & 34 & 0.2 & 7 & 2 \\
\hline $481 \mathrm{~A}-12-5$ & 152 & 473 & 4388 & 112 & 215 & 164 & 38 & 0.3 & 1 & 3 \\
\hline $481 \mathrm{~A}-13-2$ & 159 & 485 & 2347 & 58 & 102 & 248 & 144 & 3.1 & 2 & 4 \\
\hline $481 \mathrm{~A}-13-4$ & 162 & 64 & 354 & 66 & 17 & 56 & 119 & 2.5 & 1 & 5 \\
\hline $481 \mathrm{~A}-14-3$ & 169 & 161 & 284 & 21 & 37 & 55 & 16 & 0.3 & 1 & 5 \\
\hline $481 \mathrm{~A}-22-4$ & 246 & 423 & 103 & 3 & 29 & 26 & 7 & & 8 & 6 \\
\hline $481 \mathrm{~A}-22-6$ & 248 & 263 & 77 & 3.5 & 22 & 20 & 6 & & 8 & 6 \\
\hline $481 \mathrm{~A}-24-6$ & 269 & 491 & 115 & 2.8 & 34 & 25 & 6 & & 6 & 6 \\
\hline $481 \mathrm{~A}-25-6$ & 278 & 495 & 124 & 3.0 & 34 & 25 & 7 & & 6 & 7 \\
\hline $481 \mathrm{~A}-26-6$ & 287 & 434 & 111 & 3.1 & 29 & 18 & 10 & & 6 & 7 \\
\hline $481 \mathrm{~A}-27-6$ & 297 & 459 & 107 & 2.8 & 26 & 9 & 4 & & 4 & 7 \\
\hline $481 \mathrm{~A}-28-6$ & 306 & 366 & 118 & 3.9 & 29 & 10 & 5 & & 2 & 8 \\
\hline $481 \mathrm{~A}-30-7$ & 326 & 125 & 339 & 33.0 & 50 & 89 & 11 & 0.01 & 4 & 8 \\
\hline
\end{tabular}

a The $\mathrm{CO}_{2}$ data are from shipboard analyses (see site chapters).

b Very qualitative and based on shipboard temperature estimates $(1=$ low thermal stress; $10=$ high thermal stress $)$.

generally consists of hemipelagic diatomaceous ooze with thick interlayers of turbidites; the sequence varies in age from early Pliocene to Recent. Below 521 meters, the lithology changes to interlayered dolerites and basalt at a depth of 562.5 meters.

The methane concentration shows no trend with depth (Fig. 1), but ethane increases in concentration down to about 300 meters and then drops to a minimum value above the basalt. This was first explained by the high density and cementation of the sediment below 300 meters, which decelerated the liberation of ethane from the core (see site chapter). Some data support this explanation. In fact, the density of the sediment increases from $1.6 \mathrm{~g} / \mathrm{cm}^{3}$ in the upper part of the sequence to $1.8 \mathrm{~g} / \mathrm{cm}^{3}$ 
in the lower part. The upper part also contains a considerable amount of dissolved silicic acid, which is depleted at depth.

But this chapter shows that the carbon isotope composition of the methane, which does not depend on emanation conditions, reveals the same trend as that of the ethane concentration (Fig. 1). In the upper part of the sequence, the methane has a $\delta^{13} \mathrm{C}$ value (Fig. 1) typical for gases of a microbiological origin $\left(\delta^{13} \mathrm{C}=\right.$ $-75 \%$ ) (Galimov, 1975; Simoneit et al., 1979). But in the zone with the high concentration of ethane, the methane is enriched in the ${ }^{13} \mathrm{C}$ isotope, and downward in the sequence it again becomes isotopically lighter (Fig. 1). The $\delta^{13} \mathrm{C}$ values, measured in the lower part of the sequence, correspond to the common case: methane depleted in the light isotope with depth (Galimov, 1975). The methane with an isotopic composition of about $-40 \%$ does not fit this tendency and should therefore be regarded as allogenic. We know that methane with a similar isotopic composition is derived from mature organic matter by thermal transformation. The gas is relatively high in heavy hydrocarbons at this depth $(272 \mathrm{~m})$. In this context, the higher content of ethane can be accounted for by a lateral migration of hydrocarbon gas. Coarse sandy layers were encountered at a depth of 260 to 280 meters in Hole $474 \mathrm{~A}$. They could be permeable horizons, providing for the lateral migration of hydrocarbons. The samples recovered from that interval had the maximum $\delta^{13} \mathrm{C}$ value of the $\mathrm{CH}_{4}$ and highest $\mathrm{C}_{2}-\mathrm{C}_{5}$ concentrations.

Holes 475 and 476 contained no interstitial gas.

\section{Guaymas Basin}

Holes 477,478 , and 481 are in the Guaymas Basin in water depths of approximately 2000 meters. The structural geology of the region is determined by two, short, rifting axes separated by a short minor transform fault and confined by two long transform faults. The basin is in an active rift zone and has a typical oceanic crust

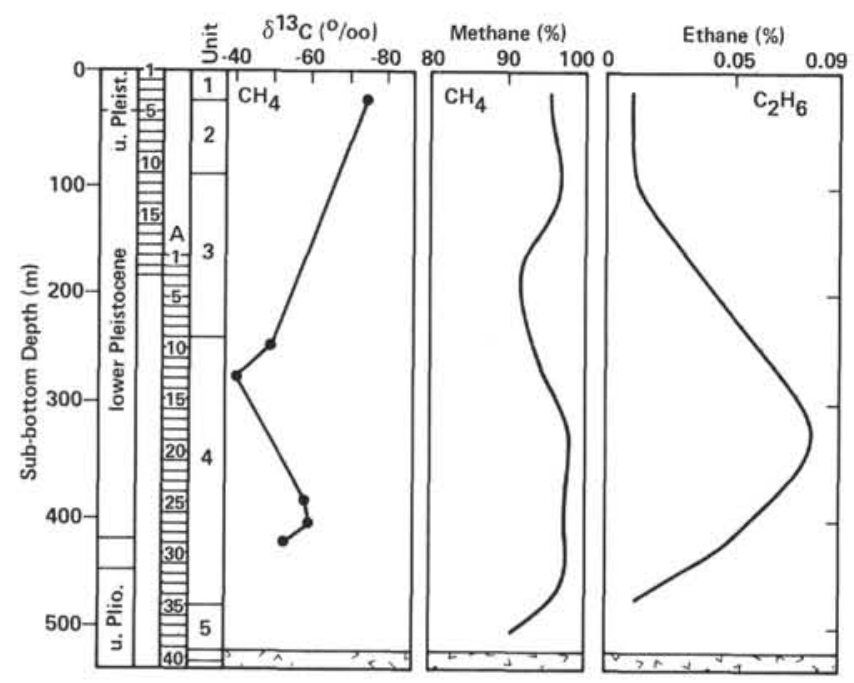

Figure 1. Plots of $\delta^{13} \mathrm{C}$ and concentrations of methane and ethane versus depth, Holes 474 and 474A.
(Moore et al., 1978). The heat flow in the basin is uneven and ranges up to about $30 \mu \mathrm{cal} \mathrm{cm}^{-2} \mathrm{~g}^{-1}$. The basin has a rather high rate of sediment accumulation $\left(2.7 \mathrm{~m} / 10^{3} \mathrm{yr}\right)$ associated with high biological productivity and, as a consequence, a rapid burial of unoxidized organic matter. The region offers an opportunity to investigate the effect of increased temperatures on diagenetically unaltered organic matter (Einsele et al., 1980).

Hole 477 is in the southern rift zone. Measurements showed extremely high values of heat flow. At a depth of 260 meters, the temperature exceeds $135^{\circ} \mathrm{C}$. The lithologic sequence consists of an upper, unaltered member of diatom turbidites $(0-58 \mathrm{~m})$, a dolerite intrusion (58$105.5 \mathrm{~m}$ ), and a lower, altered member of turbidites. The lower turbidite member has undergone extensive hydrothermal alteration.

The methane concentration in the upper section decreases with depth toward the dolerite intrusion; in the lower sequence, it increases with depth, away from the dolerite intrusion (Fig. 2). The change in carbon dioxide concentration in the sediment is exactly the opposite. The interstitial gas contains a peculiarly high concentration of $\mathrm{CO}_{2}$. Its concentration adjacent to the intrusion is $90 \%$. We found no ethane in the upper section, but below the sill, the ethane concentration increases and then decreases (Fig. 2).

The carbon isotopic analysis shows that the methane in the lower part of the sequence is depleted in the light isotope and has $\delta^{13} \mathrm{C}$ values corresponding to gases generated from organic matter at a medium stage of metamorphism (Fig. 2). Methane of similar isotopic compositions frequently accompanies crude oil (Galimov, 1975).

The gas from Core 477-19 reveals the highest value of $\delta^{13} \mathrm{C}$ and the maximum content of ethane. Thus, the lower sequences of Holes 477 and 477A contain hydrocarbon gases generated by the destruction of organic matter under extreme hydrothermal conditions.

The change in isotopic composition of the carbon dioxide (Table 2) is shown in Figure 2. The $\mathrm{CO}_{2}$ concentration decreases toward the sill and becomes isotopically heavier. The $\mathrm{CO}_{2}$ possibly resulted from a partial decomposition of carbonates from hydrothermal alteration. The increase in the concentration of $\mathrm{CO}_{2}$ may account for the enrichment of $\mathrm{CO}_{2}$ in the ${ }^{13} \mathrm{C}$ isotope near the intrusion.

Hole 478 is near the transform fault between the rifts of the Guaymas Basin. Unlike Hole 477, it has a moderate heat flow value. The sediments show no effects of hydrothermal alteration. They consist of a 300-meterthick deposit of turbidites, overlying dolerite sills. The sediment in the upper section $(0-188 \mathrm{~m})$ comprises diatomaceous ooze, with interlayers of turbidite sand. They are underlain by various dolomite sandstones and include two dolerite sills $(188-260 \mathrm{~m})$. The lower portion of the sediment contains homogeneous diatom claystones with interlayered dolomite $(260-342.5 \mathrm{~m})$. The density of the sediments does not exceed that of the Hole 474 sequence and is typical for oceanic deposits. The change in the physical boundaries of sediment throughout the sequence is less pronounced than in Hole 477. The tem- 


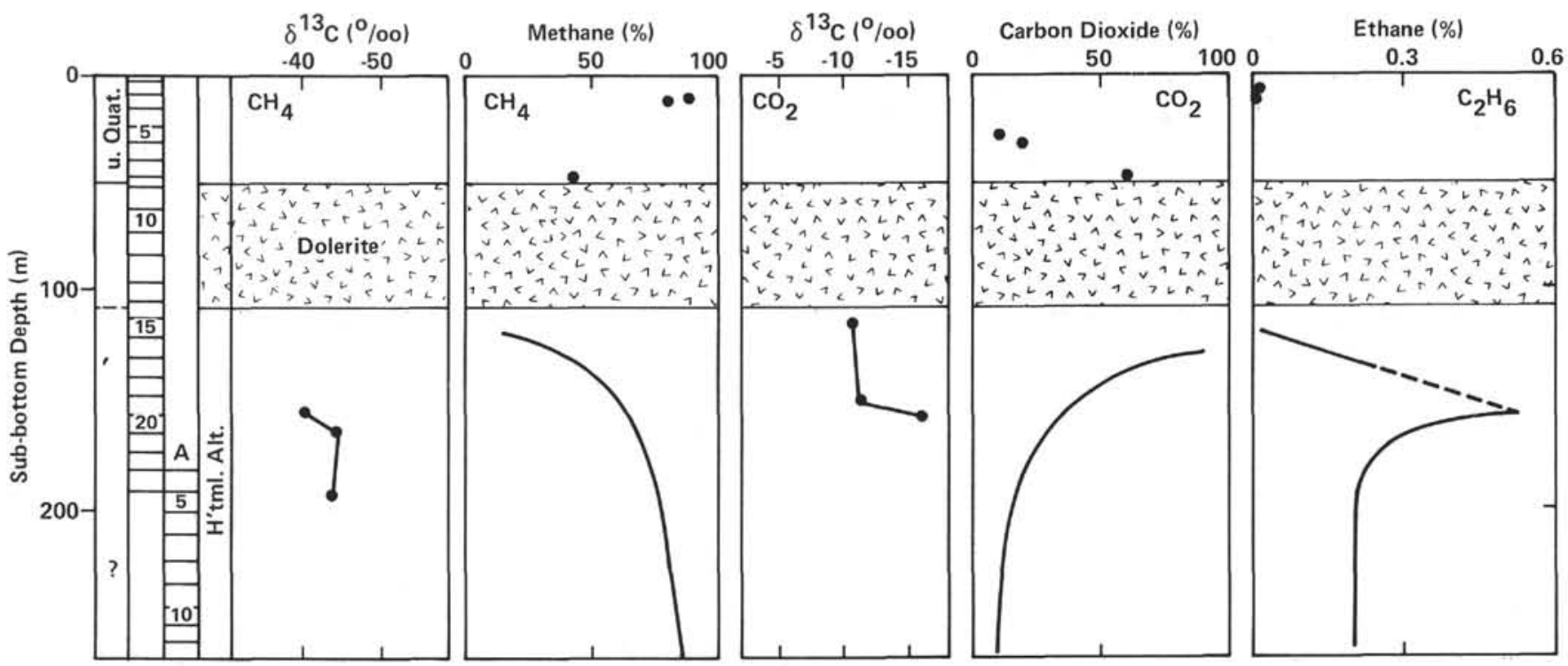

Figure 2. Plots of $\delta^{13} \mathrm{C}$ and concentrations of methane and ethane versus depth, Hole 477 .

perature effects of the intrusions are limited to the immediate contact zone (several $\mathrm{cm}$ ).

Gas composition varies only slightly throughout the sequence (Fig. 3). Ethane increases slightly with depth, but below the dolerite intrusion, it passes through a minimum.

The isotopic composition of the $\mathrm{CH}_{4}$ has a relatively low $\delta^{13} \mathrm{C}$ value, typical for methane generated from immature organic matter by microbiota. The upper part of the sequence reveals a rather rapid change in the isotopic composition of $\mathrm{CH}_{4}$ from -79.17 to $-62.46 \%$ with depth (Fig. 3). These values compare with the mean $\left(\delta^{13} \mathrm{C}\right.$ $=-71 \%$ ) for $\mathrm{CH}_{4}$ in surface sediments at station 30G in the northern rift (Simoneit et al., 1979). Farther down, the isotopic composition of methane varies approximately around the mean. These isotopic data indicate an autochthonous origin for the methane when under conditions of a moderate thermal gradient. The $\mathrm{CO}_{2}$ concentration ranges from 10 to $20 \%$ above the sills, and the $\delta^{13} \mathrm{C}$ values range from -6.3 to $-9.7 \%$ (Table 2 ). As in Hole 477, this $\mathrm{CO}_{2}$ may be derived from partial decomposition of carbonates.

Hole $481 \mathrm{~A}$ is in the northern rift of the Guaymas Basin. In the sediment above the dolerite sill, the ethane increases in concentration with depth to a maximum at about 150 meters sub-bottom (Fig. 4). Below the upper sill, the $\mathrm{C}_{2} \mathrm{H}_{6}$ concentration passes through a minimum. The $\mathrm{CH}_{4}$ concentration is approximately constant from 50 to 130 meters. It increases slightly toward the upper sill (Fig. 4) and below it passes through a maximum.

The carbon isotopic composition of the $\mathrm{CH}_{4}$ above the upper sill lightens rapidly (Fig. 4). This change is more distinct than in Hole 478. Values to about 100 meters sub-bottom are typically biogenic (Claypool and Kaplan, 1974) and compare to the $\delta^{13} \mathrm{C}=-71 \%$ for the $\mathrm{CH}_{4}$ in the surface sediment at station 30G, about 8 $\mathrm{km}$ to the northeast (Simoneit et al., 1979). The $\mathrm{CH}_{4}$ near the top of the upper dolerite sill approaches the isotopic composition of approximately $-44 \%$, which is typical of thermogenesis from mature organic matter and which corresponds to the initial phase of oil generation (Galimov, 1975). The isotopic composition of $\mathrm{CH}_{4}$ in the lower part of the sequence changes unevenly with depth, remaining, with one exception, within the range characteristic of methane at the early stage of transformation of organic matter. The presence of $\mathrm{CH}_{4}$ at 278 meters sub-bottom with $\delta^{13} \mathrm{C}=-44.4 \%$ appears to be a significant relict thermogenic component. Most of the gas below the upper sill probably formed under milder thermal regimes from relatively unaltered organic matter.

The $\mathrm{CO}_{2}$ concentrations throughout the hole are less than $10 \%$, and the $\delta^{13} \mathrm{C}$ values are scattered from -3.3 to $-20.3 \%$ ( Table 2) - data insufficient to indicate processes.

\section{Continental Slope}

Holes 479 and 480 are on the continental slope of the northeastern flank of the Guaymas Basin in water depths of 650 to 750 meters. The lithology of the sediment in Hole 479 consists of hemipelagic diatomaceous ooze and claystone with interlayered dolomite beds. The carbonate is less abundant in the upper part $(0-250 \mathrm{~m})$ than in the middle part $(250-355 \mathrm{~m})$. The amount of carbonates increases further in the lower part (355-440 m).

The $\mathrm{CH}_{4}$ concentration decreases to about $60 \%$ with depth and then fluctuates between 45 and $70 \%$ (Fig. 5). Ethane remains low and essentially constant, not exceeding $0.02 \%$ to a depth of about 260 meters (Fig. 5). But at greater depth, the $\mathrm{C}_{2} \mathrm{H}_{6}$ concentration increases to $>0.1 \%$ and accompanies the simultaneous increases of the $\mathrm{C}_{3}-\mathrm{C}_{5}$ hydrocarbons (Simoneit, this volume). Drilling in Hole 479 stopped at 400 meters because of a continuing increase in the concentrations of heavy hydrocarbons.

The isotopic composition of the $\mathrm{CH}_{4}$ varies within the range of -50 to $-70 \%$ (Fig. 5). The isotopic composition of the $\mathrm{CH}_{4}$ remains generally unaltered and 
Table 2. Carbon isotope composition of $\mathrm{CH}_{4}$ and $\mathrm{CO}_{2}$, Gulf of California (DSDP Leg 64).

\begin{tabular}{|c|c|c|}
\hline Section & $\begin{array}{c}\mathrm{CH}_{4} \\
{ }_{\delta}^{13} \mathrm{C}(\%)^{\mathrm{a}}\end{array}$ & $\begin{array}{c}\mathrm{CO}_{2} \\
\delta^{13} \mathrm{C}(\%)^{\mathrm{a}}\end{array}$ \\
\hline $474-3-3$ & -75.34 & $-b$ \\
\hline $474 A-9-4$ & -49.65 & - \\
\hline $474 \mathrm{~A}-12-4$ & -40.35 & - \\
\hline $474 A-24-3$ & -59.00 & - \\
\hline $474 A-26-2$ & -59.96 & - \\
\hline $474 \mathrm{~A}-28-2$ & -53.61 & - \\
\hline $474 \mathrm{~A}-40-3$ & $-b$ & - \\
\hline $477-7-1$ & - & - \\
\hline $477-16-2$ & - & -10.87 \\
\hline $477-19-3$ & -39.99 & -11.05 \\
\hline $477-20-2$ & -44.40 & -16.43 \\
\hline $477-23-1$ & -42.94 & - \\
\hline $478-11-3$ & -79.17 & - \\
\hline $478-14-3$ & -72.38 & -8.91 \\
\hline $478-17-3$ & -68.66 & -8.09 \\
\hline $478-20-4$ & -62.46 & -6.31 \\
\hline $478-22-1$ & -64.36 & -9.73 \\
\hline $478-28-3$ & -61.93 & - \\
\hline $478-31-1$ & -65.38 & - \\
\hline $478-33-3$ & - & - \\
\hline $478-35-2$ & -59.75 & - \\
\hline $479-14-6$ & -55.62 & +3.29 \\
\hline $479-18-2$ & -58.41 & - \\
\hline $479-20-5$ & -61.78 & -0.85 \\
\hline $479-22-5$ & -55.48 & +0.80 \\
\hline $479-24-5$ & -52.04 & +0.06 \\
\hline $479-25-2$ & -61.78 & -2.47 \\
\hline $479-27-5$ & -61.56 & -2.71 \\
\hline $479-29-5$ & -57.45 & -1.78 \\
\hline $479-31-5$ & -51.63 & -3.77 \\
\hline $479-34-5$ & -60.76 & -6.57 \\
\hline $479-36-2$ & -58.95 & -3.67 \\
\hline $479-40-4$ & -54.87 & -4.63 \\
\hline $479-43-2$ & -60.76 & -8.53 \\
\hline $479-47-3$ & -60.38 & -9.57 \\
\hline $480-21-2$ & - & - \\
\hline $480-25-1$ & -66.96 & -4.38 \\
\hline $481 \mathrm{~A}-4-1$ & -77.32 & - \\
\hline $481 \mathrm{~A}-5-3$ & -70.32 & -7.28 \\
\hline $481 \mathrm{~A}-7-6$ & -69.75 & -11.95 \\
\hline $481 A-9-5$ & - & - \\
\hline $481 \mathrm{~A}-10-5$ & -59.20 & - \\
\hline $481 \mathrm{~A}-12-5$ & -54.66 & - \\
\hline $481 \mathrm{~A}-13-2$ & -55.22 & - \\
\hline $481 \mathrm{~A}-13-4$ & - & - \\
\hline $481 \mathrm{~A}-14-3$ & -44.18 & - \\
\hline $481 \mathrm{~A}-22-4$ & -59.84 & - \\
\hline $481 \mathrm{~A}-22-6$ & - & -3.25 \\
\hline $481 \mathrm{~A}-24-6$ & -57.75 & -20.28 \\
\hline $481 A-25-6$ & -44.36 & - \\
\hline $481 \mathrm{~A}-26-6$ & -56.29 & -9.49 \\
\hline $481 \mathrm{~A}-27-6$ & -56.06 & -12.60 \\
\hline $481 \mathrm{~A}-28-6$ & -61.05 & - \\
\hline $481 \mathrm{~A}-30-7$ & -53.66 & - \\
\hline
\end{tabular}

a Versus PDB Standard.

$\mathrm{b}$ Insufficient sample for determination.

does not reflect a ${ }^{13} \mathrm{C}$-enrichment that can be related to the increase of the $\mathrm{C}_{2}-\mathrm{C}_{5}$ hydrocarbon concentration. The scatter throughout the sequence is less than $10 \%$, and the range is within values typical for $\mathrm{CH}_{4}$ derived from immature organic matter. Such a striking difference in the chemical composition of the gas and the isotopic composition of the methane can be attributed,

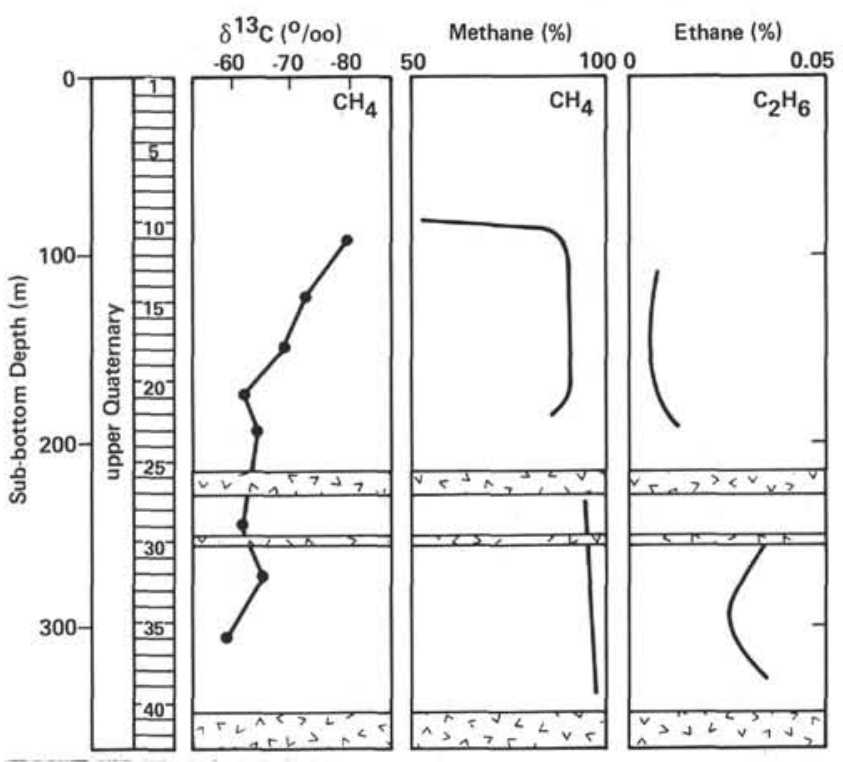

Figure 3. Plots of $\delta^{13} \mathrm{C}$ and concentrations of methane and ethane versus depth, Hole 478.

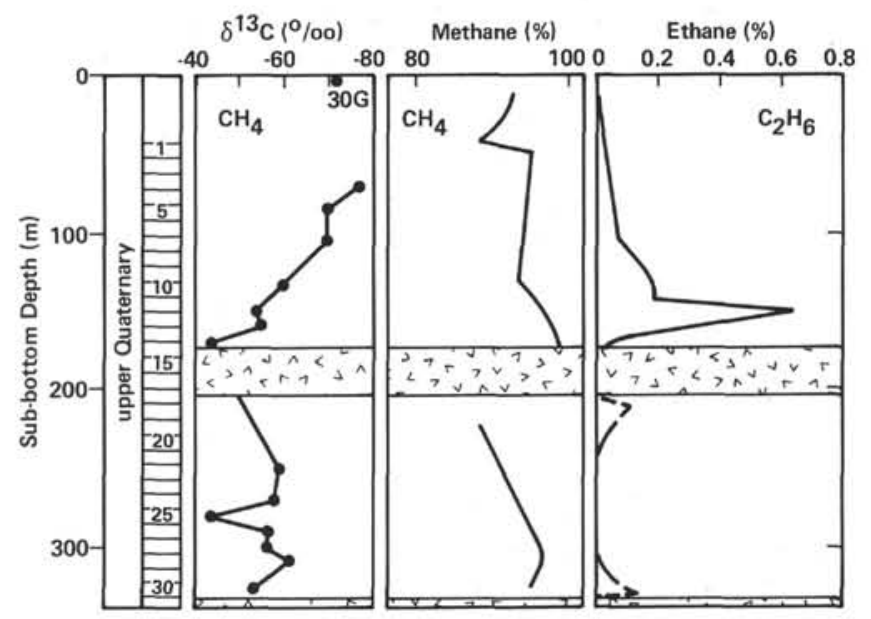

Figure 4. Plots of $\delta^{13} \mathrm{C}$ and concentrations of methane and ethane versus depth, Hole 481 .

in principle, to a diffusion of thermogenic hydrocarbons from the underlying deposits. Compared to the gas content of the sediment, the gas influx from this origin could be minor (not exceeding several percent). Therefore, the change in the isotopic composition of the $\mathrm{CH}_{4}$ could be imperceptible. But the influx of even $1 \%$ of gas with a $5 \%$ constituent of ethane, where the ethane concentration made up $0.01 \%$, could quintuple the ethane proportion of the gas; and this could explain the data.

The $\mathrm{CO}_{2}$ in Hole 479 varies in concentration from 10 to $50 \%$ and has the highest values of $\delta^{13} \mathrm{C}$ (Fig. 5 and Table 2). The $\mathrm{CO}_{2}$ isotopic composition shows a tendency to depletion of the heavy carbon isotope in the sequence. Calculations of average values from the data for all three lithologic complexes gives the following results: $\delta^{13} \mathrm{C}=0.31 \%$ for all the upper complex, $-3.9 \%$ o for the middle, and $-7.58 \%$ for the lower.

Isotopically heavy $\mathrm{CO}_{2}$ may result from the decomposition of oxygen-bearing organic compounds (e.g., 


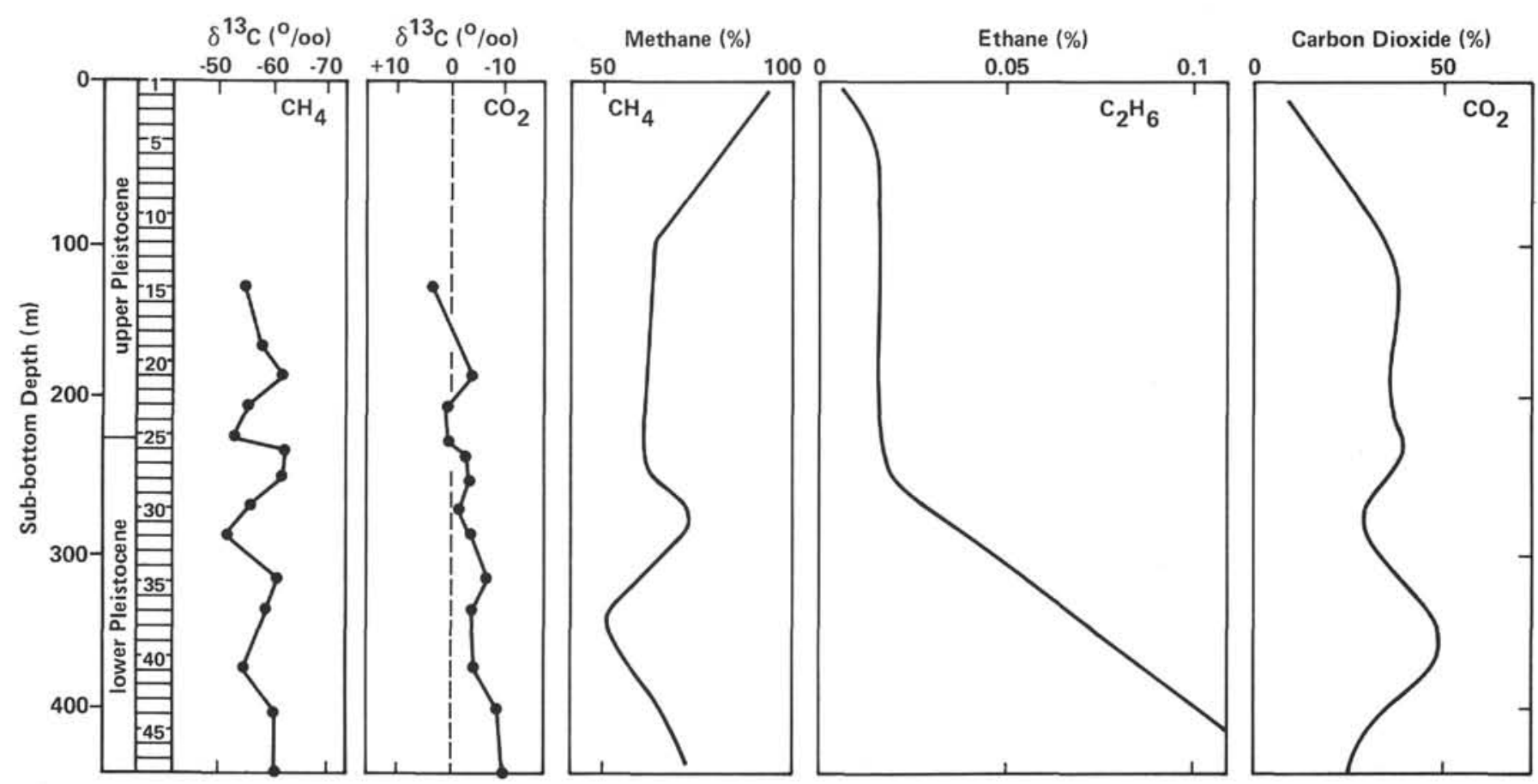

Figure 5. Plots of $\delta^{13} \mathrm{C}$ and concentrations of methane, carbon dioxide, and ethane versus depth, Hole 479.

decarboxylation) in reducing environments (Galimov, 1974) and from the microbiological reduction of some carbon dioxide to methane (Claypool and Kaplan, 1974). The high biological productivity and high rates of organic matter burial imply that sedimentation in the Site 479 hole took place in environments with an oxygen deficiency. This is confirmed by the relatively high values of $\delta^{13} \mathrm{C}$ for the $\mathrm{CO}_{2}$, particularly in the upper part of the sequence. Because of the high carbonate concentration at greater depths, the $\mathrm{CO}_{2}$ isotopic composition may possibly become a function of fractionation in the isotope exchange system $\left(\mathrm{CO}_{2}=\mathrm{CO}_{3}{ }^{-}\right)$. Analyzing this assumption requires more comprehensive data on the carbonate content and the isotopic composition of the sediment.

Hole 480 is in the same region of the marginal plateau as Hole 479. A single analysis of the interstitial gas from 119 meters sub-bottom gave the values of $\delta^{13} \mathrm{C}=$ $-66.96 \%$ for $\mathrm{CH}_{4}$ and $-4.38 \%$ for $\mathrm{CO}_{2}$. These values are slightly lower than those from Hole 479 at a corresponding depth (about $120 \mathrm{~m}$ ).

\section{Canned Samples}

Table 3 presents the results of the headspace analyses of the canned samples. The purpose of the analysis was to obtain $\delta^{13} \mathrm{C}$ data for the $\mathrm{C}_{2}-\mathrm{C}_{5}$ hydrocarbons, but the small concentrations precluded such determinations. The gas data are similar to that of Hole $479: \delta^{13} \mathrm{C}$ values of the methane are essentially in the biogenic range, and the $\mathrm{CO}_{2}$ is depleted in ${ }^{13} \mathrm{C}$ at depth.

\section{CONCLUSIONS}

The concentrations of the interstitial hydrocarbon gases $\left(C_{1}-C_{5}\right)$ determined onboard were confirmed, and we detected no olefinic hydrocarbons.
The carben isotopic composition of methane shows a trend towarc $a$ depletion of the light isotope with depth in the sedir tary sequence (Galimov, 1975). Galimov et al. (1980) also established this same tendency for a deep oceanic sedimentary sequence. This depletion results from the fact that the methane, generated at different stages of transformation of the organic matter, differs in the isotopic composition of the carbon. The following are ranges of $\mathrm{CH}_{4}$ isotopic composition (corresponding to the successive stages of organic matter transformation):

1) initial (biogenic; consisting only of methane) $\delta^{13} \mathrm{C}$ $=<-60 \%$;

2) early (onset of $\mathrm{C}_{2}-\mathrm{C}_{5}$ hydrocarbon generation) $\delta^{13} \mathrm{C}$ from $-40 \%$ to $-60 \%$;

3) mature (main phase of oil formation) $\delta^{13} \mathrm{C}$ from $-30 \%$ to $-40 \%$; and

4) late (termination of liquid hydrocarbon generation; amorphous stage of organic matter metamorphism) $\delta^{13} \mathrm{C}=>-30 \%$.

In most of the holes, the isotopic composition of methane in the upper sections, composed of sediment unaffected by thermal events caused by intrusions, corresponds to a microbiological origin (i.e., the initial stage of organic matter transformation). This is also true for the $\mathrm{CH}_{4}$ in the surface sediment from station $30 \mathrm{G}$ in the northern rift of the Guaymas Basin (Simoneit et al., 1979). But near intrusions, the methane is generally depleted in the light carbon isotope. In these sections, the change in the methane isotopic composition increases with depth. The highest values of $\delta^{13} \mathrm{C}$ for $\mathrm{CH}_{4}$ occur in Hole 477, the area with the highest heat flow values. The isotopic composition of $\mathrm{CH}_{4}$ ranges from -40 to $-44 \%$ at depths below 200 meters. Thus, the isotopic composition of methane, as a rule, accords with the thermal history of the surrounding sediment. 
Table 3. Headspace analyses of canned sediment samples from Holes 479, 481, and $418 \mathrm{~A}$.

\begin{tabular}{|c|c|c|c|c|c|c|c|c|c|}
\hline \multirow[b]{2}{*}{ Section } & \multicolumn{6}{|c|}{ Quantitative Analysis $^{\mathrm{a}}$} & \multicolumn{3}{|c|}{ Stable Isotope Composition ${ }^{b}$} \\
\hline & Methane & Ethane & Propane & Total $\mathrm{C}_{4}$ & $\mathrm{C}_{5}{ }^{+}$ & $\mathrm{CO}_{2}$ & $\begin{array}{c}\text { Methane } \\
{ }_{\delta^{1}}{ }^{13} \mathrm{C}\end{array}$ & $\begin{array}{l}\text { Carbon } \\
{ }_{\delta^{13}} \mathrm{C}\end{array}$ & $\begin{array}{r}\text { Dioxide } \\
{ }_{\delta}^{18} \mathrm{O}\end{array}$ \\
\hline $479-19-7$ & 381 & 0.34 & 0.07 & - & - & 9.7 & -59.89 & -3.78 & -1.29 \\
\hline $479-28-7$ & 102 & 0.28 & 0.04 & - & - & 4.9 & - & -5.53 & -1.35 \\
\hline $481-4, C C$ & 3190 & - & 0.08 & - & - & 2.3 & -70.08 & -4.01 & -1.34 \\
\hline $481 \mathrm{~A}-24, \mathrm{CC}$ & 486 & 0.45 & 0.15 & 0.09 & 0.16 & 1.7 & -58.34 & -10.93 & -0.58 \\
\hline
\end{tabular}

Some sediment revealed examples of gas migration. Two holes were typical. The $\mathrm{CH}_{4}$ in Hole 474, at a depth of 250 to 280 meters, was depleted in the light carbon isotope $\left(\delta^{13} \mathrm{C}\right.$ from -40 to $-50 \%$ ) in the overlying and underlying gases. This possibly resulted from horizontal migration of methane derived from the transformation of mature organic matter. Hole 479 is another example of this sequence not revealing any considerable change in the isotope composition of the methane with depth. But, a considerable increase in the concentration of hydrocarbons at depths below 300 meters implies a vertical gas diffusion from a source with a high content of heavy hydrocarbons.

Considerable concentrations of $\mathrm{CO}_{2}$ were encountered in some of the interstitial gas. In most of the cases, the isotopic composition of the $\mathrm{CO}_{2}$ carbon varies downhole without any obvious trend. The values of $\delta^{13} \mathrm{C}$, ranging from -7 to $-12 \%$, are common. They are close to the value of $-9 \%$, which corresponds to the average value of the $\mathrm{CO}_{2}$ of organic and inorganic origins. In sections with considerable carbonate concentrations, the isotopic composition of $\mathrm{CO}_{2}$ should be controlled by an exchange in the system $\left(\mathrm{CO}_{2}=\mathrm{CO}_{3}=\right)$. The enrichment of $\mathrm{CO}_{2}$ with the heavy carbon isotope (e.g., as in Hole 479) is possibly determined by generation of this ${ }^{13} \mathrm{C}$ by the anaerobic decomposition of organic matter in a sedimentary environment of acute oxygen deficiency. The $\mathrm{CO}_{2}$ may be enriched in ${ }^{13} \mathrm{C}$ in two ways. First, the carbon may combine with oxygen (e.g., carboxyl) in the biogenic organic compounds and become enriched in the ${ }^{13} \mathrm{C}$ isotope by a specific intramolecular distribution of carbon isotopes (Galimov, 1974, 1975). Second, the microbiological reduction of $\mathrm{CO}_{2}$ presumably generates a kinetic isotope effect, leading to the concentration of the ${ }^{13} \mathrm{C}$ isotope in the residual carbon dioxide (Claypool and Kaplan, 1974). The $\mathrm{CO}_{2}$ enriched in the light carbon isotope $(-16$ to $-20 \%)$ is probably a product of organic matter oxidation, and it inherits the isotopic composition of the total organic carbon.
The headspace gas of canned sediment samples contained insufficient $\mathrm{C}_{2}-\mathrm{C}_{5}$ hydrocarbons for stable carbon isotope analysis. The $\mathrm{CH}_{4}$ was primarily biogenic, and the $\mathrm{CO}_{2}$ was partly thermogenic.

\section{ACKNOWLEDGMENTS}

We thank Dr. Brian G. Rohrback for the composition and stable isotope analyses of the headspace gas of the canned samples, $\mathrm{Mr}$. Barry Latner for technical assistance, and Peter D. Jenden and H. I. Halpern for reviewing the manuscript. This is contribution No. 2089 from the Institute of Geophysics and Planetary Physics, University of California at Los Angeles.

\section{REFERENCES}

Claypool, G. E., and Kaplan, I. R., 1974. Origin and distribution of methane in marine sediments. In Kaplan, I. R. (Ed.), Natural Gas in Marine Sediments: New York (Plenum), pp. 99-139.

Einsele, G., Gieskes, J. M., Curray, J., et al., 1980. Intrusion of basaltic sills into highly porous sediments, and resulting hydrothermal activity. Nature, 283:441-445.

Galimov, E. M., 1974. Organic geochemistry of carbon isotopes. In Tissot, B., and Bienner, F. (Eds.), Advances in Organic Geochemistry 1973: Paris (Editions Technip), pp. 439-452.

, 1975. Carbon isotopes in oil and gas geology. "Nedra," Moscow, 1973, English translation by NASA, F-682, Washington, D.C., 1975.

Galimov, E. M., Chinjenov, V. A., and Ivanov, G. N., 1980. Isotopic composition of methane carbon and relative content of gaseous hydrocarbons in the deposits of the Moroccan Basin in the Atlantic Ocean (DSDP Sites 415 and 416). In Lancelot, E., Winterer, E. L., et al., Init. Repts. DSDP, 50: Washington (U.S. Govt. Printing Office), 615-622.

Moore, D. G., Curray, J. R., and Lawver, L. A., 1978. Tectonics and geological history of the Gulf of California. CIBCASIO Trans. $3 r d, 3: 66-75$.

Rohrback, B. G., 1979. Analysis of low molecular weight products generated by thermal decomposition of organic matter in Recent sedimentary environments [Ph.D. dissert.]. University of California, Los Angeles.

Simoneit, B. R. T., Mazurek, M. A., Brenner, S., et al., 1979. Organic geochemistry of recent sediments from Guaymas Basin, Gulf of California. Deep-Sea Res., 26A:879-891. 